\title{
IMPROVING MATHEMATICS LEARNING OUTCOMES OF CLASS IX MIDDLE SCHOOL STUDENTS IN THE MAJOR AREA AND FLAT BUILDING USING REALISTIC APPROACHES
}

\author{
${ }^{1}$ Asep Yusuf, ${ }^{2}$ Ruslan Mubarok \\ ${ }^{1,2}$ SMKS Tazkia Nusantara Cipanas \\ Jl. Kebun Raya Cibodas, Cianjur \\ 1asepy6353@gmail.com, ${ }^{2}$ ruslanrm@gmail.com
}

\begin{abstract}
The problem of this research is how to apply realistic mathematics to the wide discussion and the circumference of flat shapes. The aim is to identify the difficulties of junior high school students in completing story questions in broad and rounded discussion. This research method is classroom action research. Subjects of the study included students of class IX-B at SMPN 1 Campaka Mulya. The instrument tested was a test sheet containing 5 questions in the form of a description. The study was conducted in three cycles, in each cycle consisting of several stages, namely planning, implementing actions, observing, and reflecting. From the results of the study obtained information related to improving student learning outcomes. This is known from the average value and percentage of mastery learning in each cycle that is increasing. In cycle I the average value is 53.8 with completeness of learning $3.7 \%$ and included in the category of inadequate, the average value of cycle II is 75.2 with mastery learning $40.7 \%$ and included in the category enough, and the average value the average cycle III is 82.8 with mastery learning reaching $92.5 \%$ or included in the Good category. After the implementation of the action, it appears that students become more happy and enthusiastic in learning mathematics by using a realistic approach to the broad discussion and the circumference of flat shapes.
\end{abstract}

Keywords: Realistic, Two-dimentional figure, Learning Outcomes

\begin{abstract}
Abstrak
Masalah penelitian ini yaitu bagaimana menerapkan matematika realistik pada luas dan keliling bangun datar. Tujuannya untuk mengidentifikasi kesulitan siswa SMP dalam Memecahkan soal cerita luas dan keliling bangun datar. Metode penelitian ini yaitu penelitian tindakan kelas. Subjek dari penelitian mencakup siswa SMPN 1 Campaka Mulya kelas IX-B. Instrumen yang diuji cobakan berupa lembar tes yang berisi 5 soal uraian. Penelitian dilaksanakan dengan tiga siklus, di masing masing siklus itu terdiri dari beberapa tahapan yaitu perencanaan, pemberian tindakan, observasi, dan refleksi. Dari hasil penelitian diperoleh informasi terkait meningkatnya hasil belajar pada siswa. Hal ini diketahui dari rata-rata nilai serta persentase dalam ketuntasan belajar tiap siklus yang semakin meningkat. Pada siklus I rata-rata nilainya yaitu 53,8 dengan ketuntasan belajar 3,7\% dan termasuk kategori kurang, rata-rata nilai siklus II yaitu 75,2 dengan ketuntasan belajar 40,7\% dan termasuk kategori cukup, dan rata-rata siklus III yaitu 82,8 dengan ketuntasan belajar mencapai $92,5 \%$ atau masuk dalam kategori Baik. Setelah pelaksanaan tindakan terlihat siswa lebih senang dan antusias ketika belajar materi ini.
\end{abstract}

Kata Kunci: Realistik, Bangun Datar, Hasil Belajar

How to Cite: Yusuf, A., Mubarok, R. (2020). Improving Mathematics Learning Outcomes Of Class Ix Middle School Students In The Major Area And Flat Building Using Realistic Approaches. JEE, 3 (1), 19-24. 


\section{INTRODUCTION}

Mathematics is a universal science and is an indispensable lesson in education because mathematics is often used in various fields. In line with (Tarbiyah \& Ambon, 2013) mathematics is a universal science and is at the core of technological development. But until now the reality in the field are still many students consider mathematics as a very difficult field. However, everyone must learn mathematics because mathematics is one of the ways of solving problems in daily life. Education itself has a very important influence on human life and influences human survival. But there are still many people who are educated just to get good grades or get a degree. Even though the real goal is to get the knowledge to be able to solve problems in life in accordance with the times. In line with what was stated by Syafinuddin al Mandari (Vandini, 2016), the process of learning or education is a direction or instruction to act according to the rules that exist. While the value obtained is only as a measure of achievement of learning outcomes, where the achievement is not only good grades but also with changes to positive things. This opinion is also in line with that expressed by Hamdani (Achdiyat \& Lestari, 2016)

One of the subjects studied at the junior secondary level is the extent and circumference of a flat structure. The flat build is important to be learned by students because the concept of breadth and circumference is very useful in solving everyday problems. For example in calculating the area of land, the circumference of the land, the floor of a building, the amount of ceramics needed to build a construction, etc. But from the results of research in the first cycle which was used as a preliminary study, it turns out the learning outcomes in understanding the concepts of area and circumference are still quite low.

One of the success factors in learning is students get increased results. But in reality, many obstacles are found in the field. For example, until now quite a lot of people say that mathematics is one of the subjects that are quite difficult to understand. One effect is mathematics which is given in abstract form and is rarely associated with everyday life. Besides that, there are still many students who find it difficult to change story problems into mathematical models. Therefore we need the accuracy of the approach in delivering the discussion to be given. One way to do this is to apply a realistic approach to the discussion of flat shapes, where students can be directly involved in finding concepts by being associated with concrete objects around them or in daily life. In accordance with the background of the problem, the formulation of the research problem is how to apply a realistic approach in the broad discussion as well as the circumference of a flat structure? and whether by applying this approach, learning outcomes in students of SMP Negeri 1 Campaka Mulya in class IX-B can be improved? This research has to improve student learning outcomes in broad areas as well as the circumference of flat shapes. Learning in a realistic manner is one of the things that can be used as an appropriate learning solution because with this learning approach a student is asked to know his abilities and knowledge through a series of activities during learning according to the instructions of the teacher concerned by linking the discussion of learning material into activities of daily life as one part of human activity.

The Introduction presents the purpose of the studies reported and their relationship to earlier work in the field. It should not be an extensive review of the literature. Use only those references required to provide the most salient background to allow the readers to understand and evaluate the purpose and results of the present study without referring to previous publications on the topic. 


\section{METHOD}

This research took place at SMPN 1 Campaka Mulya which is located in Campakamulya Village, Campakamulya District, Cianjur Regency. This research is qualitative research with Classroom Action Research. The study was conducted in 3 cycles. Related to the collection of data is done by using a test sheet and observation of test results which are then collected after the implementation of these actions in each cycle, to be able to know the knowledge and abilities of students related to this material. This technique can be used as a measurement of learning outcomes or student achievement towards learning undertaken.

Cycle I was conducted in one meeting only to know the initial ability in advance, which was used as a preliminary study by giving a test sheet in the form of 5 question descriptions. Cycle II was held in two meetings. At the first meeting, learning preparation is done by creating a learning group, then the learning process takes place through the action in the form of applying a realistic approach to discuss material that is associated with objects that are in the classroom or close to students. The next meeting was held again to test the learning outcomes. While in cycle III, it was also held in two meetings. Almost the same as the previous one, namely the preparation of learning through group formation and providing active learning through a realistic approach but even more enhanced as an improvement to the shortcomings of the previous meeting.

Improvement of learning outcomes for each student can be seen from the calculation of the average value of each cycle so that it can be seen changes or improvements in learning outcomes. The research action procedures that have been carried out are students considered complete if the value is $\geq 75$, and the grade completeness is a minimum of $85 \%$ of the total students who scored 75.

\section{RESULTS AND DISCUSSION}

\section{Results}

From trials conducted by researchers, it can be seen the ability and knowledge of students at SMPN 1 Campaka Mulya have different characteristics, some are sufficient, good, and very good.

\section{Cycle I}

In cycle I, students' abilities are still low because there is only 1 person who has reached or exceeds 75 , with details as follows:

Table 1. Learning Cycle I Results

\begin{tabular}{cc}
\hline Many students & Score \\
\hline 1 & 80 \\
1 & 65 \\
6 & 60 \\
19 & 50 \\
Average & 53,8 \\
\hline $\begin{array}{c}\text { Percentage of mastery } \\
\text { learning }\end{array}$ & $3,7 \%$ \\
\hline
\end{tabular}


The results at the beginning of the cycle based on the test have the aim of knowing the basis or beginning of students' abilities. Test results at the beginning of the cycle, in the form of an assessment of the test sheet that must be solved or completed by students. Of the 27 students, 26 students entered the incomplete group with details of 19 people getting a value of 50, then 6 people getting a grade of 60 and 1 person getting a value of 65 . While students entering the complete category were only 1 person, with a value of 80 or only $3.7 \%$ of 27 students. The initial ability before action the average value of students of SMP Negeri 1 Campaka Mulya in class IX-B was 53.8 with a level of mastery learning of the class only $3.7 \%$.

This cycle shows that there are still quite a lot of students who haven't finished or got low grades. The problem in this cycle is that students are still oriented towards formulas and lack understanding of concepts from the periphery or broad. Besides that, there are still many students who find it difficult to change story problems into mathematical models. Because of these problems, interesting learning is needed again so that learning outcomes can improve in subsequent cycles.

\section{Cycle II}

In cycle II, learning outcomes are improved after being given action, this can be seen from the average value that increased to 75.2 and the percentage of graduation learning by $40.7 \%$ with details as follows:

Table 2. Learning Cycle II Results

\begin{tabular}{cc}
\hline Many students & Score \\
\hline 1 & 100 \\
3 & 90 \\
1 & 85 \\
3 & 80 \\
3 & 75 \\
14 & 70 \\
2 & 65 \\
Average & 75,2 \\
\hline Percentage of mastery & $40,7 \%$ \\
\hline
\end{tabular}

The second cycle of learning is carried out in two meetings. The first meeting starts with preparing students to be able to follow the learning and explain the learning objectives. Then a study group is formed based on the attendance number, followed by discussion actions by applying the approach in accordance with the steps stated (Yuhasriati, 2012), namely guiding students to find concepts, connect with real-life or concrete objects around the class and develop learning with student activities as the center. Then the next meeting was closed with the test again through a test sheet containing 5 questions. The results of the second cycle test are obtained from students' answers on the test sheet. The result is that 16 students enter the group not complete or KKM has not been achieved, with the record 2 people get a value of 65 and 14 people the value is 70 . While 11 other students fall into the category of complete namely 3 people with a value of 75,3 people get a value of 80,1 person get a value of 85,3 people get a value of 90 and 1 person get a value of 100 . The average value in this cycle is 75.2. This means an increase compared to the results in the initial cycle, where students who entered the complete category were $40.7 \%$ but did not meet the minimum grade completeness of $85 \%$. In addition, student activities are also more active when learning takes place, but 
some students still have difficulty when solving mathematical problems, especially in story problems.

\section{Cycle III}

In the last cycle which is the final result that is $92.5 \%$ of students have finished learning by achieving the KKM value, with notes as follows:

Table 3. Learning Cycle III Results

\begin{tabular}{cc}
\hline Many students & Score \\
\hline 2 & 100 \\
3 & 90 \\
8 & 85 \\
9 & 80 \\
3 & 75 \\
2 & 70 \\
Average & 82,8 \\
\hline Percentage of mastery & $92,5 \%$ \\
learning
\end{tabular}

The next learning is the third cycle which is almost similar to the previous cycle with two meetings. The first meeting begins with the researcher preparing students to begin learning and providing motivation to students to get learning outcomes that are improved compared to previous results. But in this cycle, the researchers tried to change the way the formation of groups of students with a grouping system based on heterogeneous levels of ability. In line with (Hasbullah, 2014) students can interact with their respective groups to be able to solve mathematical problems given because, with their peers, students become active and dare to express opinions in a discussion, with the hope that students will have confidence and be motivated to follow learning mathematics seriously and passionately. Then the researchers tried to explain again related to this material using realistic concepts. Cycle III is the conclusion or final analysis to determine the learning outcomes of class IX-B. At the end of the meeting, the researcher again gave a test to find out the final abilities and grades obtained by students, all of them more than 65 namely 2 people with a value of 70,3 people with a value of 75,9 people with a value of 80,8 people with a value of 85,3 people with a value of 90 and there were 2 people with the highest score of 100 . The increase in the average grade also rose quite well by 82.8 . This shows that 25 students or $92.5 \%$ of all grade IX-B students have completed and fulfilled the class completeness target of $85 \%$. In addition, students are also enthusiastic and more active when learning takes place. According to the results of the study, it can be seen the influence of a realistic approach to learning outcomes that increase. This can be seen from the average value and percentage of mastery learning for each cycle, with details such as the following:

Table 4. Average and Mastery Learning

\begin{tabular}{ccc}
\hline Cycle & Average & $\begin{array}{c}\text { Percentage of } \\
\text { Mastery Learning }\end{array}$ \\
\hline I & 53,8 & $3,7 \%$ \\
\hline II & 75,2 & $40,7 \%$ \\
\hline III & 82,8 & $92,5 \%$ \\
\hline
\end{tabular}


Based on the results of the three cycles that have been carried out, it turns out that the results of applying a realistic approach to the material of flat shapes about the area or its circumference are quite influential. This is seen through learning outcomes that continue to increase in each cycle. The first cycle of the average value of 53.8 students with mastery learning only $3.7 \%$, while in the second cycle, the average value to 75.2 with mastery learning $40.7 \%$, and the third cycle which is the average result the value reached 82.8 with $92.5 \%$ mastery learning.

\section{CONCLUSION}

Based on the data analysis and discussion, it is concluded that the final results of learning for students of SMP Negeri 1 Campaka Mulya in class IX-B in the discussion around and flat area increased significantly, as the influence of a realistic mathematical approach. This can be known from the results of tests in cycle I, cycle II, and cycle III which are then collected after the implementation of these actions in each cycle. Details of the average value of the first cycle of 53.8 or included in the category less, the average value of the second cycle is 75.2 or included in the medium category and the average value of the cycle III is 82.8 or included in either category. With these improved results, it shows that using a realistic approach when learning mathematics about the broad and perimeter discussion of a flat figure works optimally as an appropriate learning solution. Besides that, after the action is implemented, the students' activity seems to change for the better. Activities during learning according to the direction of the teacher concerned For example students become seen happy and interested in learning mathematics. Students become enthusiastic in learning, students work on problems in earnest and full of concentration to get maximum results.

\section{REFERENCES}

Achdiyat, M., \& Lestari, K. D. (2016). Prestasi Belajar Matematika Ditinjau dari Kepercayaan Diri dan Keaktifan Siswa di Kelas. Formatif: Jurnal Ilmiah Pendidikan MIPA, 6(1), 5061. https://doi.org/10.30998/formatif.v6i1.752

Hasbullah. (2014). Pengaruh Metode Belajar dan Rasa Percaya Diri Terhadap Hasil Belajar Matematika Siswa, 4(2).

Saefudin, A. A., Yogyakarta, U. P., Pgri, J., \& No, S. (2013). Pendidikan Matematika Realistik Indonesia (PMRI). Jurnal Pendidikan. https://doi.org/10.22342/jme.1.1.791.11-16

Simatupang, R., \& Surya, E. (2017). Meningkatkan Hasil Belajar Matematika Siswa Melalui, (October).

Tarbiyah, F., \& Ambon, I. (2013). Jurnal matematika dan pembelajarannya 2013, 1(1), 17-31.

Vandini, I. (2016). Peran Kepercayaan Diri terhadap Prestasi Belajar Matematika Siswa. Formatif: Jurnal Ilmiah Pendidikan MIPA, 5(3), 210-219. https://doi.org/10.30998/formatif.v5i3.646

Yuhasriati. (2012). Pendekatan Realistik dalam Pembelajaran Matematika. Jurnal Peluang. 